\author{
БОБРОВА Ю. Ю., \\ докторка юридичних наук, \\ доцентка кафедри правового \\ забезпечення \\ (Військовий інститут Київського \\ начіонального університету \\ імені Тараса Шевченка), \\ суддя \\ (Біловодський районний суд Луганської \\ області)
}

БОБРОВ Ю. О., кандидат юридичних наук, полковник юстиції, Заслужений юрист України, суддя

(Івано-Франківський окружний адміністративний суд), начальник (Управління правового забезпечення Генерального штабу Збройних Сил України - начальник юридичної служби Збройних Сил Украӥни) 
годні кримінальні провадження у справах про кримінальні правопорушення, вчинені військовослужбовцями, розглядають судді, які не мають елементарного досвіду військової служби. Крім того, враховуючи концентрацію військ на сході України і територіальний принцип судочинства, часто такі справи вирішують судді, котрі у той чи інший спосіб пов'язані з тимчасово окупованими територіями Донецької та Луганської областей: раніше проживали там, мають родичів на непідконтрольній Україні території тощо, а отже, не можуть приймати неупереджених, законних і справедливих рішень у кримінальних провадженнях про військові злочини та про злочини, вчинені військовослужбовцями. На сучасному етапі суспільного розвитку наша держава не змогла створити умови для ефективного судового захисту прав, свобод та законних інтересів військовослужбовців, адже військові суди досі так і не створені, а територіальні суди загальної юрисдикції, до компетенції яких належить такий захист, не забезпечують його в повному обсязі та в належний спосіб у зв'язку з певними об'єктивними і суб'єктивними обставинами.

Ключові слова: військовий суд, суддя, військовий конфлікт, військовослужбовеиь, військові злочин, Міжнародний кримінальний суд.

\section{Bobrova Yu. Yu., Bobrov Yu. O. Determinants and the road map for the reconstruction of military courts in Ukraine}

War, like trouble, does not come alone. Destruction, mutilated human destinies and selected lives go hand in hand with it. In the context of the restoration of justice, the only rational solution would be to punish the aggressor by bringing him to justice and obtaining appropriate satisfaction. The legal mechanism for implementing this is the International Criminal Court in The Hague (the so-called Hague Tribunal), which operates on the basis of the Rome Statute; the jurisdiction of this court extends only to those States which have ratified it. It is clear that Russia never acknowledges its invasion of Ukraine, despite the obvious facts and indisputable evidence. Moreover, after the statement of the Prosecutor of the International Criminal Court Bensuda, the Russian media wrote that "the Hague will finally deal with the Ukrainian military". The fact is that the International Criminal Court accepts a case or factual circumstances if the state of Ukraine does not bring its servicemen to disciplinary, administrative or criminal liability for violations. This is because there are no military courts in Ukraine that operate successfully in Russia and a number of other countries at war.

This state judicial institution existed until September 2010 and was liquidated due to certain subjective and objective factors. At present, criminal proceedings in cases of criminal offenses committed by servicemen are considered by judges who do not have basic experience of military service. In addition, given the concentration of troops in eastern Ukraine and the territorial principle of justice, such cases are often decided by judges who are in one way or another connected with the temporarily occupied territories of Donetsk and Luhansk regions: therefore, they cannot make impartial, lawful and fair decisions in criminal proceedings concerning war crimes and crimes committed by servicemen. At the present stage of social development, our state has failed to create conditions for effective judicial protection of the rights, freedoms and legitimate interests of servicemen, because military courts have not yet been established, and territorial courts of general jurisdiction, which have such protection, do not provide it in full to the extent and in an appropriate manner, in connection with certain objective and subjective circumstances.

Key words: military court, judge, military conflict, serviceman, war crimes, International Criminal Court.

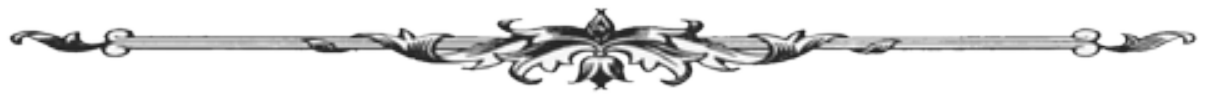


Вступ. Україна, будучи у стані гібридної війни, хоч і підписала, але не ратифікувала Римський статут. Однак на підставі двох заяв Верховної Ради від 17 квітня 2014 року і від 8 вересня 2015 року, поданих до Міжнародного кримінального суду, наша держава надала йому юрисдикцію щодо двох ситуацій: можливе вчинення злочинів проти людяності під час Революції гідності (з 21 листопада 2013 року до 22 лютого 2014 року) і можливе вчинення злочинів проти людяності та воєнних злочинів на всій території України, починаючи з 20 лютого 2014 року (саме із цього дня ми ведемо відлік російської агресії) по теперішній час [1].

Росія теж не ратифікувала Римський статут, ба більше, у 2016 році після публікації звіту прокурора Міжнародного кримінального суду Фату Бенсуди про дії за попереднім розслідуванням справи «Ситуація в Україні», де визначено ситуацію в Криму рівнозначною міжнародному збройному конфлікту між Україною і Росією - остання відкликала підпис під Римським статутом.

Станом на сьогодні ряд політичних сил лобіюють ратифікацію Україною Римського статуту, мотивуючи це тим, що в разі встановлення причетності конкретних російських політиків, військовослужбовців і чиновників до злочинів, скоєних на території України, щодо них на території інших держав буде безстроково діяти Ордер Міжнародного кримінального суду на арешт i доставку їх до МКС із внесенням їх до бази даних Інтерполу. Ефективність наведеного механізму притягнення російських військовослужбовців до кримінальної відповідальності $є$ сумнівною, однак однозначним $є$ те, що це дозволить росіянам надіслати надумані, сфабриковані багатотисячні томи справ проти українських військових до МКС, а самі ж вони уникнуть відповідальності.

Так, у червні 2014 року у Слідчому комітеті Російської Федерації створили «спецпідрозділ із розслідування злочинів міжнародного характеру, вчинених в Україні». Об'єктом уваги даного органу став вищий керівний склад Збройних сил України. Відомо, що Слідчий комітет розслідує понад 230 кримінальних справ стосовно наших військових, які брали участь у проведенні АТО і ООС на території Донецької та Луганської областей. У рамках досудового розслідування заочно пред'явлено звинувачення близько 70 українських військовослужбовців керівної ланки за фактом «злочинів проти людяності, використання зброї масового ураження» і тому подібної брехні [1]. Підставою для таких дій став принцип універсальної юрисдикції, який дозволяє притягати до кримінальної відповідальності громадян нашої держави на території України за скоєння військових злочинів за умови непроведення Україною розслідування. Загальновідомо, що, застосовуючи універсальну юрисдикцію, держава, має керуватися високим ступенем небезпеки наслідків злочину для людства в цілому. Російські правознавці запевняють, що даний принцип закріплений у частині 3 статті 12 КК РФ, Женевських конвенціях від 1949 року і Додаткових протоколах до них.

Що ж стосується України, то в Генпрокуратурі в жовтні 2017 року було створено Управління з розслідування злочинів, скоєних на тимчасово окупованих територіях. У ході досудового розслідування офіційно прийнято рішення про закриття кримінальних проваджень щодо 89 військовослужбовців ЗСУ та Міністерства оборони України (100 фактів), у тому числі керівництва Генерального штабу, колишнього міністра оборони Полторака i його заступників у зв'язку з відсутністю в їхніх діях складу злочину. Паралельно з цим Генпрокуратура вела досудове розслідування щодо працівників Слідчого комітету Російської Федерації, які сприяють терористичним організаціям «ДНР» і «ЛНР». На жаль, це управління в кінці 2019 року розформували. Таким чином, фактично припинено роботу українських органів досудового розслідування щодо військових, проти яких порушені справи Слідчим комітетом РФ, що ускладнює якісне формування правової позиції в міжнародних судових органах із цих питань та прийняття обгрунтованих і справедливих рішень щодо українських військовослужбовців, яких СК РФ безпідставно звинувачує у скоєнні злочинів. Створений у структурі Офісу генерального прокурора України у грудні 2019 року Департамент нагляду у кримінальних виробництвах щодо злочинів, скоєних в умовах збройного конфлікту на тимчасово окупованих територіях, на жаль, не вирішує тих завдань із розслідування військових злочинів країни-агресора на території України, які виконувало управління.

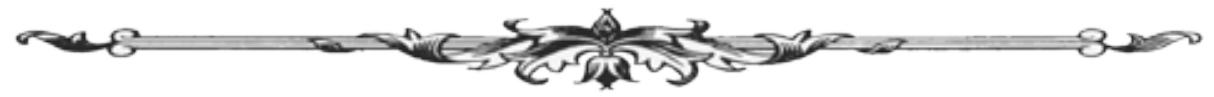


Зауважуємо, що матеріали до Міжнародного кримінального суду можуть подати і громадські організації. Так, у 2015 році в Донецьку була створена громадська комісія 3 фіксації військових злочинів, пізніше вона перетворилася в громадську організацію «Справедлива захист», яка збирає «докази» злочинів, нібито скоєних військовослужбовцями ЗСУ. Вона передала до Міжнародного кримінального суду матеріали більш ніж про 1800 постраждалих. До слова, активістами цієї організації є: постійний учасник брифінгів про «обстріл ВСУ» Олександр Копил, експерт-криміналіст, доктор юридичних наук, підполковник міліції у відставці, колишній викладач Донецького національного університету Олександр Моісеєв, адвокати Олена Шишкіна та Олена Коваленко, фахівець в області права Максим Овсієнко; координує їхню діяльність офіцер ФСБ Дмитро Гордєєв (уродженець Донецька, проживає в Ростовській області, працював політтехнологом у Придністров'і, 3 квітня 2014 року позаштатний кореспондент ITAP-TACС в Донецьку). Насправді інформація донецького «Справедливого захисту» сфальсифікована. Вона спростована даними Державної прикордонної служби (при перетині КПВВ офіційно опитували потерпілих, про які заявляв «Справедлива захист»; були вказані прізвища людей і їх адреси). Як з'ясовувалося - ці люди жодних заяв в офіційні органи взагалі не подавали. Ба більше, понад дві третини «офіційних фактів», поданих росіянами і окупаційними властями «ЛНР» і «ДНР» до Міжнародного кримінального суду і до Свропейського суду з прав людини, є надуманими. На противагу їм подані наші матеріали. Так, у 2017 році була створена робоча група, до складу якої увійшли співробітники Управління правового забезпечення Об' єднаного оперативного штабу, управлінь Генерального штабу, департаментів Міністерства оборони для вивчення й аналізу офіційних звітів уповноваженого верховного комісара ООН із прав людини, які видаються щоквартально; відслідковування офіційної російської преси, сайтів «ДНР» і «ЛНР», їхнього місцевого пабліку та ін. За результатами роботи складено перелік можливих порушень міжнародного гуманітарного права: зафіксували 80 випадків, по 18 з них порушено кримінальні провадження. Існує висока ймовірність, що інші 62, поки не вивчені правоохоронними органами України, будуть предметом розслідування Офісу прокурора Міжнародного кримінального суду. А Міжнародний кримінальний суд приймає до провадження справи або фактичні обставини, якщо держава Україна не притягає своїх військовослужбовців за порушення до дисциплінарної, адміністративної або кримінальної відповідальності. Це відбувається тому, що в Україні відсутні військові суди, які успішно функціонують у РФ та ряді інших країн, які перебувають у стані війни, що є найвагомішою детермінантою відновлення їхньої діяльності.

Аналіз останніх досліджень та публікацій. Сьогодні в нашій державі майже немає спеціальних праць, які б висвітлювали досліджувані питання. Більша частина наукових праць, присвячених вказаній тематиці, датується 2000-2008 роками, а тому майже не відповідає сучасним умовам. Особливо це важливо за наявного воєнного конфлікту на сході України та процесу трансформації управління Збройними Силами України та силами оборони держави відповідно до стандартів НАТО. Науково-теоретичним підгрунтям стали роботи дослідників з актуальних питань судоустрою, зокрема: В.Й. Вільгушанського, В.В. Долежана, А.М. Колодія, М.І. Козюбри, В.Т. Маляренка, М.М. Михеєнка, Л.М. Москвич, І.В. Назарова, А.О. Селіванова, О.В. Скрипнюка, Ю.М. Тодики, Ю.С. Шемшученка, O.X. Юлдашева, О.І. Ющика та інших. Організаційно-правові засади діяльності військових судів досліджували, зокрема, такі вчені: О.М. Лощихін, С.В. Оверчук, Я.Я. Романовський, М.М. Сенько, О.С. Ткачук, В.В. Топчій, В.П. Шевченко, В.І. Шишкін та інші. Особливу цінність становили праці зарубіжних учених, а саме: В.М. Борисенка, Л.О. Воскобітової, Г.О. Жиліна, А.Я. Петроченкова, М.О. Петухова, Ю.М. Старілова, Л. Канія, Р. Остафінські, М. Заборскі та інших.

Постановка завдання. Метою статті є аналіз детермінантів відновлення військових судів задля формулювання плану дій та заходів із їх успішного функціонування в Україні.

Результати дослідження. На сучасному етапі розвитку судова система не здатна в повному обсязі реалізувати завдання зі здійснення судочинства у фактичних умовах війни

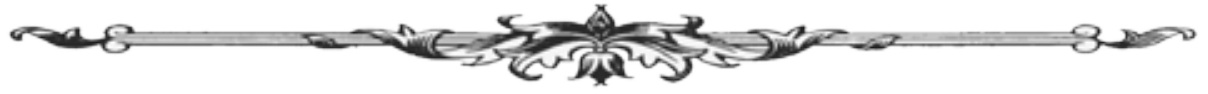


щодо саме військових кримінальних правопорушень чи значної категорії кримінальних правопорушень, вчинених військовослужбовцями. Це значною мірою стосується суддів, які відправляють судочинство безпосередньо на сході України, оскільки справ зазначеної категорії зосереджено найбільше там, хоча в достатній кількості їх спостерігається на всій території держави. Страх за власну безпеку та безпеку рідних, враховуючи погрози, що часто надходять із території ОРДЛО, наявність майна, родини на території, непідконтрольній українській владі, «кадровий голод», велике навантаження, відсутність гарантій особистої безпеки - навряд чи може йтися про повну безсторонність, неупередженість суду в «прифронтових районах». Багато хто з таких суддів заявляє самовідвід у розгляді кримінальних проваджень, зокрема щодо тероризму, участі в незаконних військових формуваннях тощо. Однак частина суддів слухає вказані справи, ставлячись поблажливо до учасників незаконних військових формувань та сепаратистів. Однак найгіршим $є$ те, що суддям, котрі здійснюють правосуддя, не вистачає елементарних знань та досвіду з розгляду військових злочинів, не враховуються особливості розгляду кримінальних проваджень про інші злочини, вчинені військовослужбовцями. Вони не розбираються в низці військових питань, зокрема тих, які пов'язані з веденням бойових дій та рішеннями, що приймаються командирами в бойовій обстановці, порядку виконання бойових завдань, питань підлеглості військовослужбовців, взаємовідносин між ними та інших питань, що мають суттєве значення для встановлення істини у справі. Однак не тільки вказані причини впливають на ефективність розгляду цієї категорії справ суддями загальної юрисдикції. Окрім наведеного, необхідно враховувати, що переважна більшість «цивільних» суддів не мають елементарного уявлення про особливості військової служби та специфіку розгляду пов'язаних із нею справ. Окрім знання норм матеріального і процесуального права, їм необхідно застосовувати статути Збройних Сил України, законодавство з питань проходження військової служби та численні підзаконні нормативно-правові акти воєнного відомства (наказів, директив, положень інструкцій тощо), про існування яких раніше не знали взагалі. Значні труднощі викликає допит свідків у вказаних справах, який згідно з вимогами КПК України не може проводитися поза приміщенням суду, а військові, які виконують бойові завдання, не можуть прибути на судовий розгляд в умовах виконання бойових завдань. Ще один момент пов'язаний із тим, що розгляд справ про військові злочини може бути пов'язаний із державною таємницею. При цьому не всі судді територіальних судів загальної юрисдикції мають до неї доступ та не в кожному суді для цього обладнане спеціальне приміщення.

До моменту ліквідації військових судів у вересні 2010 року Законом України «Про судоустрій України» встановлювалось, що військові суди належать до судів загальної юрисдикції і здійснюють правосуддя у Збройних Силах України та інших військових формуваннях, утворених відповідно до закону [2]. Військовими судами вважались: військові суди гарнізонів, апеляційні військові суди регіонів та апеляційний суд Військово-Морських Сил України. Окрім цього, як касаційна інстанція у складі Верховного Суду України діяла Військова судова палата (раніше - Військова судова колегія). 3-поміж інших суддів суддю військового суду вирізняло саме те, що він перебував на військовій службі у Збройних Силах України та мав звання офіцерського складу, які присвоювались Президентом України за поданням Голови Верховного Суду України. Правовою гарантією його незалежності була заборона залучати до виконання інших обов'язків військової служби, окрім здійснення правосуддя. Такий суддя добре знав військове законодавство, взаємовідносини в армійському колективі, військові правила і традиції, які мають велике значення у військовому середовищі.

До компетенції військових судів було віднесено розгляд кримінальних справ та справ про адміністративні правопорушення, вчинені військовослужбовцями та військовозобов'язаними під час проходження ними зборів. Причому військовим судам гарнізонів як судам першої інстанції були підвідомчі справи про злочини осіб, які мають військове звання до підполковника (капітана другого рангу) включно, крім тих справ, які були підвідомчі військовим судам вищого рівня. Військовим судам регіонів, Військово-Морських Сил України

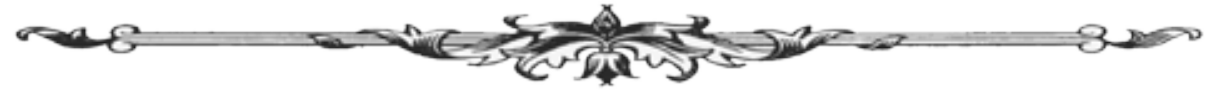


як судам першої інстанції були підвідомчі справи про злочини осіб, які мають військове звання полковника (капітана першого рангу) і вище, справи про злочин осіб, які займають посаду від командира полку, командира корабля першого рангу і вище, а також осіб, рівних їм за службовим становищем.

До діяльності військових судів відносяться по-різному. Щодо відновлення їхньої діяльності, то $є$ багато як прихильників, так і критиків.

Критика військових судів полягає в тому, що:

- існування військових судів не узгоджується з принципами спеціалізації та територіальності, що визначені в Конституції України та Законі України «Про судоустрій і статус судів»;

- військові суди $є$ альтернативою надзвичайним та особливим судам;

- у світі простежується тенденція скорочення сфери діяльності військової юстиції;

- функціонування цих судів суперечить вимогам статті 6 Конвенції про захист прав людини і основних свобод та практиці Європейського суду з прав людини;

- судді, які мають офіцерські звання, є залежними від військового командування;

- таке судочинство не відповідає демократичним принципам правосуддя; тощо [3].

- справи, які розглядаються військовими судами, не мають якихось особливостей

Специфіка завдань, покладених на військові формування, наявність великої кількості зброї, безумовно, потребує і значної за обсягом роботи з попередження злочинності серед військовослужбовців. У зв'язку із цим склалася багаторічна характерна тільки для військових судів практика розгляду певної категорії справ безпосередньо у військових частинах у ході виїзних судових засідань. Наявна підсудність справ у місцевих судах за територіальним принципом не може бути такою дієвою, як у військових судах, територіальна підсудність справ яких пов'язана з наявною структурою дислокації військових формувань. Остання дає змогу зробити ці суди доступними для людей, значно скоротити час розгляду справ.

Тривалий час, практично з початку отримання нашою державою незалежності, точилися дискусії, чи потрібні нам в Україні військові суди, оскільки на них було незначне навантаження, а їх існування визнавалося недоречним та недемократичним. Армія з кожним роком все більше розвалювалась, скорочувалися військові частини, продавалося озброєння. Населенню це все демонстрували під виглядом переходу до стандартів НАТО та світових стандартів збройних сил. Крім того, противники існування військових судів закидали щодо їх недемократичності та залежності від військового керівництва. Ситуація, що нині склалася в Україні, та громадянське суспільство вимагають утворення військових судів.

Реалізація проекту про утворення військових судів у нашій державі позитивно вплине на стан військової дисципліни та правопорядку в армійських підрозділах за рахунок компетентного та оперативного розгляду справ у розумні строки i, як наслідок, неухильного дотримання принципу верховенства права, невідворотності покарання, сприятиме поверненню віри військових у справедливість та довіри до судової влади. Судді військових судів не будуть залежними від тих впливів, які на сьогодні є на суддів із районів АТО (ООС). Діяльність військових судів у складі судової влади держави повністю усуває вплив на них 3 боку будь-кого, зокрема вплив військового чи політичного керівництва держави. I найголовніше - права військовослужбовців будуть надійно захищені компетентним судом.

Висновки. Історія розвитку та досвід військового судочинства підтверджує, що необхідність функціонування військових судів зумовлена особливою правовою регламентацією правовідносин, пов'язаних із проходженням громадянами військової служби, додатковими вимогами до кваліфікації суддів, які повинні мати грунтовні знання в галузі не тільки права, а й військової справи. Відновлення діяльності військових судів в Україні повинно бути вирішене шляхом внесення необхідних змін до чинного законодавства про судоустрій, з урахуванням вимог сьогодення, викликаних анексією частини суверенної території України - АР Крим та збройним конфліктом на сході країни і тимчасовою окупацією окремих районів Донецької та Луганської областей, а також внутрішніх і зовнішніх пріоритетів розвитку держави.

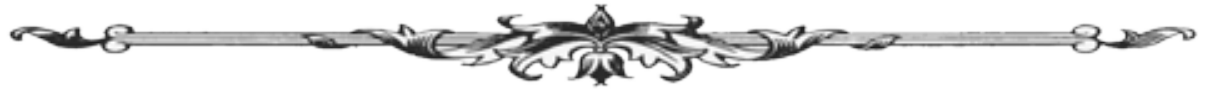




\section{Список використаних джерел:}

1. Бобров Ю.А. В Гааге есть механизмы привлечения политиков и военных РФ к ответственности за преступления на Донбассе. URL : https://ukrainenews.fakty.ua/364073-vgaage-est-mehanizmy-privlecheniya-politikov-i-voennyh-rf-k-otvetstvennosti-za-prestupleniyana-donbasse (дата звернення: 01.09.2021).

2. Про судоустрій України : Закон України від 7 лютого 2002 року № 3018-III. Втрата чинності від 03.08.2010. URL : http://zakon.rada.gov.ua/laws/show/3018-14 (дата звернення: 01.09.2021).

3. Оверчук С.В. Військові суди - необхідна складова військової юстиції в Україні. Часопис Національного університету «Острозька академія». Серія «Право». 2015. № 1(11). C. 1-21.

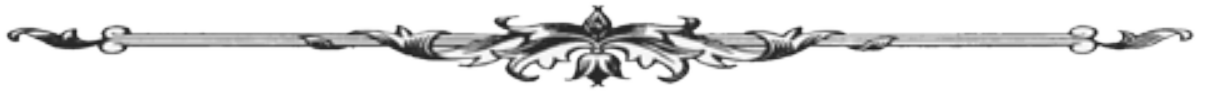

